\title{
AUTOMATION, LEISURE AND YOUTH SERVICES
}

\begin{abstract}
$\mathrm{T}$ WO short debates in the House of Commons on June 19 and June 22 complement earlier debates in the House of Lords on automation on April 8 and on tho problem of leisure on May 13 (see Nature, 202, 629; 1964; and 203,$1 ; 1964)$. In the first of these debates, a motion of Mr. C. Curran was agrecd, calling on the Government to state its policy for improving still further the educa. tional facilities provided for less-gifted children who may otherwise be excluded from an automated labour market. This motion had been framed in view of the social consequences that follow when automation increases production by using a smaller labour force and when people below a certain minimum standard of ability and education may consequently find it hard to obtain employment. As the motion indicates, Mr. Curran was concerned with the social consequences of automation and with the less-able children with whom the Newsom Report was specially concerned (see Nature, 201, 1; 1964). $\mathrm{H}_{\Theta}$ thought it would be most unwise to limit their secondary education to technical instruction: lack of literacy and the ability to communicate was likely to be a much more serious handicap to them than any lack of acquired skill. This found strong support in the debate; for example, Colonel Sir Harwood Harrison paid a warm tribute to the work of the county civic colleges, and pointed out that all education should seok to help a boy or girl to live a fuller life and to be more self-reliant. Mr. R. E. Prentice stressed the need to develop within the framework of Government techniques of forecasting man-powor which would enable us to discern where redundancies and shortages were likely to occur. Britain's education and training policies should be geared to this kind of forecasting. He anticipated in future a much larger demand for skill and education in the working population as a whole and thought that there was much potential talent at present unused. He urged the importance of expanding the youth service and asked whether the Government had accepted the interim target of an increase of 50,000 day-release places a year for the next five years recommended by the Henniker Heaton Committee of the Ministry of Education. Mr. Dudley Smith, like Mr. Prentice, referred to the importance of leisure and sport, stressing the need to inculcate a better sense of civic purpose and responsibility in the community as a whole, while Sir Barnett Janner described the successful working
\end{abstract} of youth clubs in Leicester.

The Joint Under-Secretary of State for Education and Science, Mr. C. Chataway, replying on the debate for the Government, while wolcoming the motion, discounted the idea that automation was likely to lead to any serious shortage of work. After referring to the work of the Interdepartmental Committee dealing with the general theme of 'the schools and society', Mr. Chataway said that one of the tasks of the new Schools Council, to be set up as an independent representative body with Sir John Maud as chairman, would be to foster the circulation of ideas in the schools. Its first meeting would be in October and the main function of the body would be to keep under roviow curricula, teaching methods and examinations in Britain's primary and secondary schools. He thought that the naw Council was likely to stimulate much more research and devolopment, and he pointed out that tho context within which the recommendations of the Newsom Report must be pursued had been subtly altered by the Government's acceptance of the main recommendations to raise the school-leaving age. $\mathrm{He}$ also stressed the importance of the problem of relevance between school and work. Much more was now required to bridge the gap between school and work, and he thought a major co-operative effort involving the Government, trade unions, employers and many other bodics and organizations, besides the Schools Council, was needed if this problem was to be tackled seriously. We should know much more than we do about the qualities school leavers ought to possess if they were to move easily from school to work and from one form of employment to another in later life.

In opening the debate on leisure and sport, Mr. J. P. W. Mallalieu pressed for better facilities for enjoying all forms of leisure. Besides greater support for the National Playing Fields Association, the Central Council for Physical Recreation and the Youth Hostels Association, as well as for music and drama, he pressed for more regional surveys of the needs and facilities for enjoying leisure, but centrally co-ordinated. Mr. Chataway, who followed, said that the building programme for youth clubs was now running at $£ 4.5$ million a year, compared with less than $£ 1$ million before the Albemarle Committee Report, and by this spring about 700 projects had been finished. By midsummer 1963 Britain had nearly 1,000 youth leaders against the target of 1,300 set by the Albemarle Committee for 1966 and a further 200 were in training at recognized centres. A major need was to widen the appeal of the Youth Service and to devise and extend new approaches to the less purposeful kind of youths. Since 1960-61, capital expenditure on facilities for sport and recreation had risen from $£ 5 \cdot 6$ million to an cstimated $£ 22.5$ million in 1964 .

In replying to a later debato, the Secretary of State for Science and Education, Mr. Q. Hogg, referred to the importance of seeing that, when Government expenditure on youth services was increased, it was done so intelligently and purposefully. Discussing Mr. Mallalieu's suggestion for a senior Cabinet Minister responsible for leisure, Mr. Hogg thought that this was unlikely to provide a satisfactory solution to the problem. $\mathrm{He}$ had originally been attracted by the idea of a sports development council, but now was moving away from it--for administrative reasons. He thought that the present arrangoments, with a small central organization to co-ordinate the work of the voluntary bodies, the local education authorities and Government departments had won general confidence and were working well. Developments had been rapid both on the arts side and in sports. Expenditure on the arts had risen from $£ 3$ million in 1951 to $£ 13 \cdot 5$ million, and developments in museums, entertainments, adult education and educational broadcasting had enlarged almost beyond recognition the spectrum of culture and recreation in leisure in Britain. On sport, he said that there was a more liberal policy of grants and capital expenditure to amateur sports clubs; these grants are now available to single-purpose, and not, as before, multi-purpose authorities. Grants to composite bodies, such as the Councils for Physical Recreation and National Playing Fields Association, were increasing and Britain had liberalized her loan policy to local autborities. It was also hoped to have a series of sports development councils on a local basis throughout Britain. 